\title{
FEM Simulation of Electric Car Chassis Design with Torsional Bar Technology
}

\author{
Nanang Ali Sutisna ${ }^{1}$ and M. Fajar Aulia Ansela Akbar $^{2}$ \\ Mechanical Engineering, President University \\ JABABEKA Education Park Jl. Ki Hajar Dewantara, Cikarang Utara, Bekasi 17550 \\ 1nanang.ali@presiden.ac.id, ${ }^{2}$ auliisfajar@gmail.com
}

\begin{abstract}
Abstrak
Sebuah rancangan chasis kendaraan listrik disajikan, khususnya simulasi FEM digunakan untuk mensimulasikan berbagai jenis beban dan reaksi pada kerangka kendaraan. Tujuan utama dalam penelitian ini adalah untuk mengembangkan mobil listrik dengan torsion bar, di mana frame akan memiliki sistem suspensi sendiri. Desain bingkai akan dibuat sebagai peralatan asli. Penelitian ini akan fokus pada bagaimana sasis mobil listrik menahan beban tertentu dengan kondisi batas yang ditentukan, di mana analisis dilakukan menggunakan Metode elemen hingga menggunakan perangkat lunak ANSYS. Analisis utama adalah VonMisses Stress, faktor keamanan, lentur, tegangan geser dan getaran torsion.
\end{abstract}

Kata kunci: Mobil Listrik, Chassis, Metode Elemen Hingga, Von-Misses, Faktor Keamanan, Bending, Torsion Shear Stres, Getaran, ANSYS

\begin{abstract}
A design of electrical vehicle chasis is presented, specifically a FEM simulation is employed to simulate the different kind of load and reaction on vehicle frame. The main goal in this research is to develop an electric car with torsion bar, where the frame will have a self-suspension system. The frame design will be made as original equipment. This research will focus on how an electric car chassis withstand certain load with a defined boundary condition, where the analysis is conducted using Finite element Method using ANSYS software. The main analysis is the Von-Misses Stress, the safety factor, bending, torsion shear stress and vibration.
\end{abstract}

Keywords: Electric Car, Chassis, Finite Element Method, Von-Misses, Safety Factor, Bending, Torsion Shear Stress, Vibration, ANSYS

\section{Introduction}

Electric car is one of the non-emissions vehicles that are progressing towards becoming one other option to smother the quantity of air pollution. When an electric car uses a renewable energy sources such as solar power plant, hydroelectric power plant to recharge the power source, it will smoother the air pollution. But the reality is some electric car still uses coal power plant to generate electricity that recharge the cars battery. In other cases, natural gasses power plants to charge the electric car's power source may results in less harmful air pollution. So yes it smoothers the air quality in the road, but it does not smoother the air quality around the power plant. Analysts at the Laboratory of Electric Machinery, the Department of Electrical and Electronic Engineering, Kitami Institute of Technology, Hokkaido, Japan Marwan Rosyadi said fossil vitality, for example, coal, oil, and petroleum gas will be depleted in the following 2050. So in order to save the environment, if the electric car is going to replace combustion car, it has to have a renewable energy source. Besides, electric car also has many advantages such as no noise pollution, which can results in a better living environment. It has better 
efficiency, so it will results in a great driving performance. Many famous car manufacturers outside of Indonesia has already developed electric car, for example the Tesla Model S P100D, Nissan Leaf, Toyota Prius and many more. Thus, further researches are being conducted towards electric car development.

The development can come from many aspects such as the car mileage, the time to charge the power source, the cars weight, since an electric car has more weight than common combustion car. This is due to the weight of the power source, and other components inside an electric car. Thus, with so many components on the vehicle, one of the problems that will arise is the weight that must be supported by the frame of this electric car.

In order to create a strong chassis for an electric vehicle, we need to consider the loads and the dynamics aspects that will occur in the mechanical parts such as the frame or the car's chassis. This research will be focusing on electric vehicle chassis particularly on how the self-suspension technology combined with the frame design could withstand an amount of loads that are being forced on them.

\section{Method}

\section{Finite Element Method}

Finite element method is a numerical method for solving mathematical physics [2]. The scopes of the problems are fluid flow, structural analysis and many more. Finite Element Method has the ability to solve static and dynamics problem. In this case, it is suitable for the researcher's analysis regarding electric vehicle chassis. In the static case, it is possible to count manually even though it will require a lot time. But the main reason why we need to follow the calculation method of finite element is for the dynamic analysis. Through finite element method we can get some advantages:

- Less calculation time.

Counting manually will consume a lot of time not to mention for the dynamic analysis. It will requires more effort, more time, and the researcher wanted to use his time wisely so it will results in a productive analysis. Imagine counting a chassis, not a beam, chassis in a velocity of $40 \mathrm{~km} / \mathrm{h}$ constant and we need to calculate the torsion shear at a dynamic state. It will require huge effort. Counting moment and shear for a beam even in static state manually requires a lot of steps. First you need to draw the figure, determine whether the moment will move counter clockwise or clockwise, then count the moment by determining the force, determine the $d$ or length, and so on. That is why using finite element method and ANSYS as it tools can save a lot of time.

- Less cost.

It does not require the researcher to build the model in real life to see what happens towards the chassis if it is applied by a given load. It is going to be even harder to see for example, to count the moment, the shear stress at a dynamic condition. Imagine the struggle to move the chassis at the given velocity. That is why it is effective to reduce cost.

\section{Finite Element Analysis using Tools}

There are steps in finite element analysis [8]. If the researcher is going to use this method, it is wise to follow the given steps: 


\section{Establishing the Finite Element Tools}

The Design of the chassis as explained from the previous section will be done by using SOLIDWORKS. And as for the Finite Element Method tools, the analysis will be done by using ANSYS.

\section{Establishing the Finite Element Mesh.}

Since we are going to use ANSYS as the finite element method tools, there is a feature called automatic meshing. But the researcher will not depend on the automatic meshing. Before we start we need to discuss what is meshing. Imagine a big component which will be applied by a given load. In order for the load to be distributed uniformly, the big components will be divided into smaller pieces called element. This is called meshing. The smaller the mesh sizing, the smaller the pieces are. This process is called mesh sizing. There are also different types of meshing. Triangle element are usually used in a two dimensional component. As for hexahedron, tetrahedron, pyramid, are usually use in three dimensional component. Now let's go back to our main discussion regarding how to establish a finite element mesh sizing. The problem on putting the mesh size is not as simple as putting numbers on a calculator. The problem is the mathematics of it. Understanding let say if we give a load in the component, how will the loads are passed on. If it is regarding a real life component, there are equation such as integration, matrix and stuff. We know and understand this equation in a decent level, yet the problem is, if we are going to count them without ANSYS as our tools, the time we spend on counting them will be long. So we need an approximation. And that is where finite element method plays a role as our approximation towards real life situation. Use FEM tools such as ANSYS as a simulation. That is why we need meshing as our approximation towards a real life conditions. One of the easiest ways if we use manual calculation, the equation is:

$$
[\mathrm{F}]=[\mathrm{K}][\mathrm{X}]
$$

Yes, it is on a matrix form. Where we all know [F] stands for force (in matrix form in this case), $[\mathrm{K}]$ is the stiffness matrix and $[\mathrm{X}]$ is the answer we are searching for, the force result. $[\mathrm{F}]$ and $[\mathrm{X}]$ matrix are usually written as:

$$
\{F\}=E=\left\{\begin{array}{c}
F_{1} \\
F_{2} \\
F_{3} \\
F_{4} \\
F_{5} \\
\cdot \\
\cdot \\
\cdot \\
\cdot \\
\cdot \\
F_{N}
\end{array}\right\} \quad\{X\}=x\left\{\begin{array}{c}
X_{1} \\
X_{2} \\
X_{3} \\
X_{4} \\
X_{5} \\
\cdot \\
\cdot \\
\cdot \\
\cdot \\
\cdot \\
X_{n}
\end{array}\right\}
$$

So if we are going to search for $[\mathrm{X}]$, we need to invert. So the formula will be:

$$
\left[\mathrm{K}^{-1}\right][\mathrm{F}]=[\mathrm{X}]
$$

Let's just assume the matrix is going to be three times three. The problems on counting it manually is if, let say there a lot of zeros in the matrix, at the time we invert it, times the zero with zero, the result will be zero. Yes it is a small but can be a huge problem if we count a lot of zero in the matrix. This will takes a lot of time and effort. Or let say the matrix is bigger. For example the matrix of order a. to invert it, we need to perform a $\mathrm{x}$ a $\mathrm{x}$ a using Gauss elimination. Human error on calculating can 
occurred. My whole point is, we need to search how to have an accurate result in less time. Now let's get back to mesh sizing. As the researcher has discussed before, the smaller the mesh size, the more elements we have. The more elements we have, the more accurate the result is. But what happened when the CPU does not have the computational power to calculate yet we still insist on using a small meshing size. The result of the FEM tools will not be precise. That is why; there is a method for meshing called refinement. So we don't have to give a small mesh size in the whole components. Just give the small mesh size at the area with the biggest impact. Yet how do we know the mesh size is small enough. We need to do am actual experiment to determine it.

\section{Solving the Equation}

In this step the researcher needs to define and derive an equation. For example, let say the researcher wanted to define Stress-Strain relationship in a one dimensional deformation in x direction. In order to complete the stress analysis Hooke's law is often used. The law that makes stress and strain has a relation is called the constitutive law. Now, back to Hooke's law, the equation is:

$$
\sigma_{\mathrm{x}}=\mathrm{E} \varepsilon_{\mathrm{x}}
$$

Whereas the $\sigma_{\mathrm{x}}$ is stress and $\mathrm{E}$ is Young Modulus. After we define the stress equation, next we derive the element stiffness matrix and equations or the [K]. Last is to solve the unknown or [X].

\section{Results}

After we calculate, the result will emerge. Thus the result needs to be examined. The word examines means assuming we are having the same case as in step number three. We need to know where does the largest stress occurs, where are the location of the greatest deformation occurs, and etc. The result sometimes can be in form of report preview, or graphic charts in case of using ANSYS as FEM tools. This ends the FEM steps.

\section{Manual Calculation Analysis}

It is wise to use another approach for comparison. The researcher will compare the computational analysis data with manual calculation. The calculation will be following these steps:

\section{Assumptions}

The frame will consist of more than one beam. Those beam will be joined together to create the wanted design. Yet, it is possible to calculate the whole design but it will require a lot of time. The simplest way is to build an assumption. To count the static structural lets imagine a go kart frame from the side view. Whether the beam is triangle, rectangle, circular it will appear from the side view as a rectangle shape beam. So now imagine a beam from the side view. The beam has fixed support in each end. As for the load, the frame will withstand two loads. The first load is the drivers' load which is 100 $\mathrm{kg}$. And the second is the machines load with the weight of $30 \mathrm{~kg}$. Each load has different length from the fixed support. Yes this analogy or assumption will logically have different amount of results. Since we assume the frame only consist of one beam. But the main point of this step is, imagine if this one beam is capable of withstanding the force that has been given. Imagine what four beams can do. Using this step we can see which assumption fits the most. In this step we can see which assumption has the nearest amount of result with the ANSYS analysis. So from these facts we can make two assumptions which are:

- Assuming the frame as a beam with two fixed support, yet it has different spacing.

- Assuming the frame as a beam with two fixed support, yet it has equal spacing

From these two assumptions, we can proceed to the next step. 


\section{Load Placement}

The researcher uses both assumptions to solve the analysis. Due to be noted, as for the load placement, we will have a lot more data comparison if we put one load on each calculation. Since there are two loads, the drivers load and the machines load. The load placement will be as follows:

- Drivers load $(100 \mathrm{~kg})$ using the first assumption.

- Machines load $(30 \mathrm{~kg})$ using the first assumption.

- The drivers load and the machine load in total $(130 \mathrm{~kg})$ using the first assumption.

- The drivers load and the machine load in total $(130 \mathrm{~kg})$ using the second assumption.

\section{Calculation Method}

Since there are two assumptions, there will be two calculations approach.

The first assumption
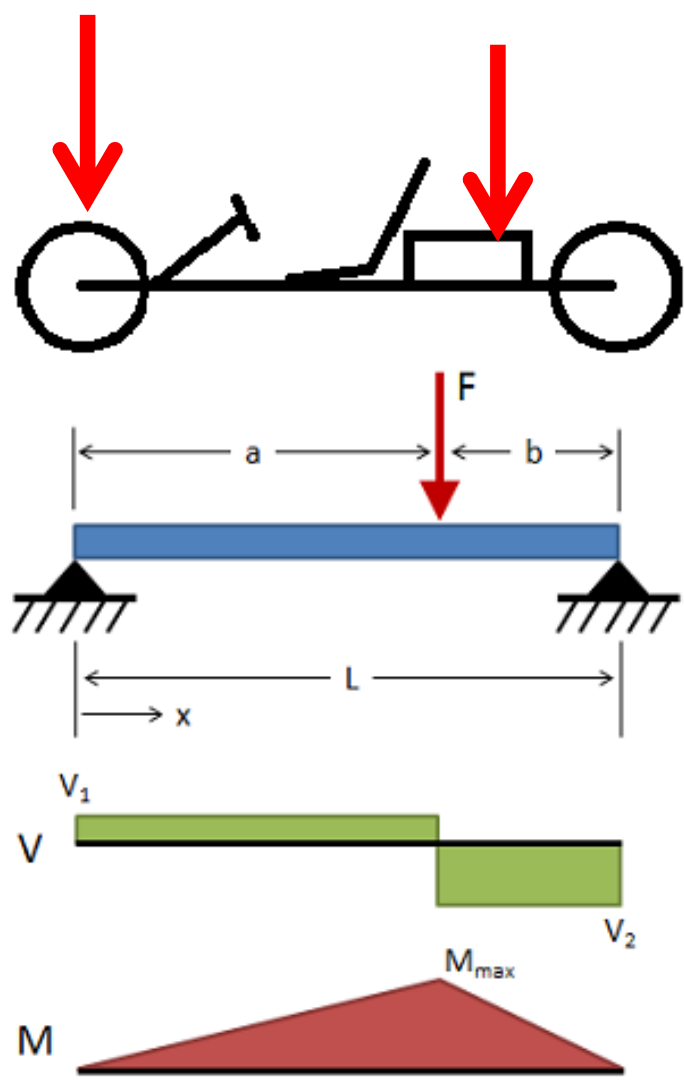

Figure 1. Assumption 1

Based on James M. Gere [3], Budynas-Nisbett [1] and Linderburg [6] from mechanical [4], an association of engineering, on the topic of beam analysis, the first assumption of the manual calculation equation will be as follows:

- Moment

$$
\mathrm{M}=\frac{\mathrm{Fab}}{\mathrm{L}}
$$

- Inertia

$$
I=\frac{\pi}{64}\left(D^{2}-d^{2}\right)
$$


Journal of Mechanical Engineering and Mechatronics

ISSN: 2527-6212, Vol. 3 No. 2

(C) 2018 Pres Univ Press Publication, Indonesia

- $\quad$ Stress

$$
\sigma=\frac{\mathrm{MY}}{\mathrm{I}}
$$

- Deflection

$$
\delta=\frac{\text { Fbx }}{6 \mathrm{LEI}}\left(\mathrm{L}^{2}-\mathrm{b}^{2}-\mathrm{x}^{2}\right)
$$

- Maximum Deflection

$$
\delta_{\max }=\frac{\mathrm{Fb}\left(\mathrm{L}^{2}-\mathrm{b}^{2}\right)^{\frac{3}{2}}}{9 \sqrt{3} \mathrm{LEI}}
$$

- $\mathrm{X}$

$$
x=\sqrt{\frac{L^{2}-b^{2}}{3}}
$$

The Second assumption
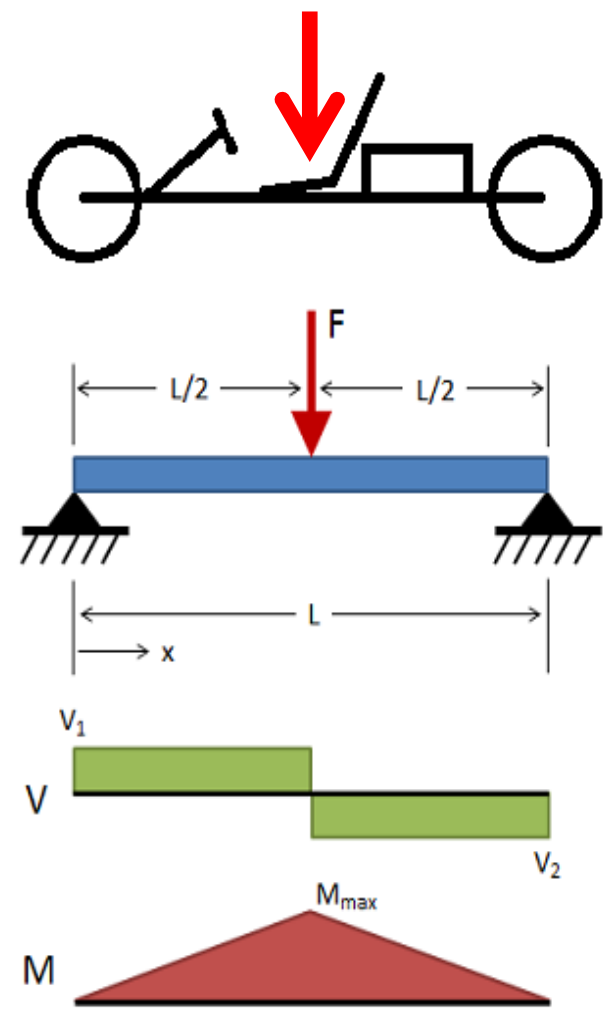

Figure 2. Assumption 2 
Based on James M. Gere [3], Budynas-Nisbett [1] and Linderburg [6] from mechanical [4], an association of engineering, on the topic of beam analysis, the second assumption of the manual calculation equation will be as follows:

- Moment

$$
\mathrm{M}=\frac{\mathrm{FL}}{4}
$$

- Inertia

$$
I=\frac{\pi}{64}\left(D^{2}-d^{2}\right)
$$

- Stress

$$
\sigma=\frac{M Y}{I}
$$

- Deformation

$$
\delta=\frac{F x}{48 \mathrm{EI}}\left(3 \mathrm{~L}^{2}-4 \mathrm{x}^{2}\right)
$$

- Maximum Deformation

$$
\delta_{\max }=\frac{\mathrm{FL}^{3}}{48 \mathrm{EI}}
$$

- $\mathrm{x}$

$$
\mathrm{x}=\frac{\mathrm{L}}{2}
$$

\section{Evaluation}

After the calculation is finished, the numbers can be compared with Yield Strength of Material $\left(\sigma_{y}\right)$, the design will be using AISI 4130 with the yield strength of $7.1 \times 108 \mathrm{~Pa}$. Allowable Stress $\left(\sigma_{A}\right)$, according to R.S. Khurmi[9], the safety factor at a static for a steel is 4 . Thus we can calculate the allowable Stress which is as follows:

$$
\begin{gathered}
\sigma_{\mathrm{A}}=\frac{\sigma_{\mathrm{y}}}{\text { Fos }} \\
\sigma_{\mathrm{A}}=\frac{7.1 \times 10^{8} \mathrm{~Pa}}{4} \\
\sigma_{\mathrm{A}}=177.5 \times 10^{6} \mathrm{~Pa}
\end{gathered}
$$

\section{Result and Discussion}

Table 1. Frame Dimension

\begin{tabular}{|c|c|c|c|}
\hline \multicolumn{3}{|c|}{ Dimesnion } & Material \\
\cline { 1 - 2 } $\begin{array}{c}\mathrm{W} \\
(\mathrm{mm})\end{array}$ & $\begin{array}{c}\mathrm{L} \\
(\mathrm{mm})\end{array}$ & $\begin{array}{c}\mathrm{H} \\
(\mathrm{mm})\end{array}$ & \multirow{2}{*}{ AISI 4130 } \\
\cline { 1 - 2 } 1000 & 1400 & 1000 & \\
\hline
\end{tabular}


Table 2. Pipe Dimension

\begin{tabular}{|c|c|c|}
\hline \multicolumn{2}{|c|}{ Dimension } & Material \\
\cline { 1 - 2 } ID (in) & OD (in) & \multirow{2}{*}{ AISI 4130 } \\
\cline { 1 - 2 } 0,76 & 1 & \\
\hline
\end{tabular}

1. Load Specification

Frame load: $14,85 \mathrm{~kg}$

Frame load + driver and machine load: $144.85 \mathrm{~kg}$

2. Mesh Sizing

The Mesh comparison will be from 10 different samples of sizes.

Table 3. Mesh Sizing Comparison

\begin{tabular}{|c|l|c|c|c|}
\hline No. & $\begin{array}{c}\text { Mesh Size } \\
(\mathbf{m m})\end{array}$ & Nodes & $\begin{array}{c}\text { VM } \\
\left(\mathbf{n} \times \mathbf{~ 1 0}^{\mathbf{7}}\right)\end{array}$ & \% \\
\hline 1. & 0.014 & 53095 & 5.204 & $\begin{array}{l}\text { Initial } \\
\text { Value }\end{array}$ \\
\hline 2. & 0.013 & 58522 & 5.512 & 5.91 \\
\hline 3. & 0.012. & 67107 & 6.1704 & 10.6 \\
\hline 4. & 0.011 & 76635 & 6.3574 & 3.03 \\
\hline $\mathbf{5 .}$ & 0.010 & 79650 & 6.4509 & 1.44 \\
\hline 6. & 0.009 & 92596 & 6.9930 & 8.4 \\
\hline 7. & 0.008 & 119546 & 7.7955 & 11.46 \\
\hline $\mathbf{8 .}$ & 0.007 & 157283 & 10.59 & 35.84 \\
\hline 9. & 0.006 & 222183 & 11.504 & 8.6 \\
\hline $\mathbf{1 0 .}$ & 0.005 & 327501 & 12.746 & 10.79 \\
\hline
\end{tabular}

After we collect all the mesh size data, we can proceed to the next step which is making the graphic. Below are the graphic generated from the results table: 


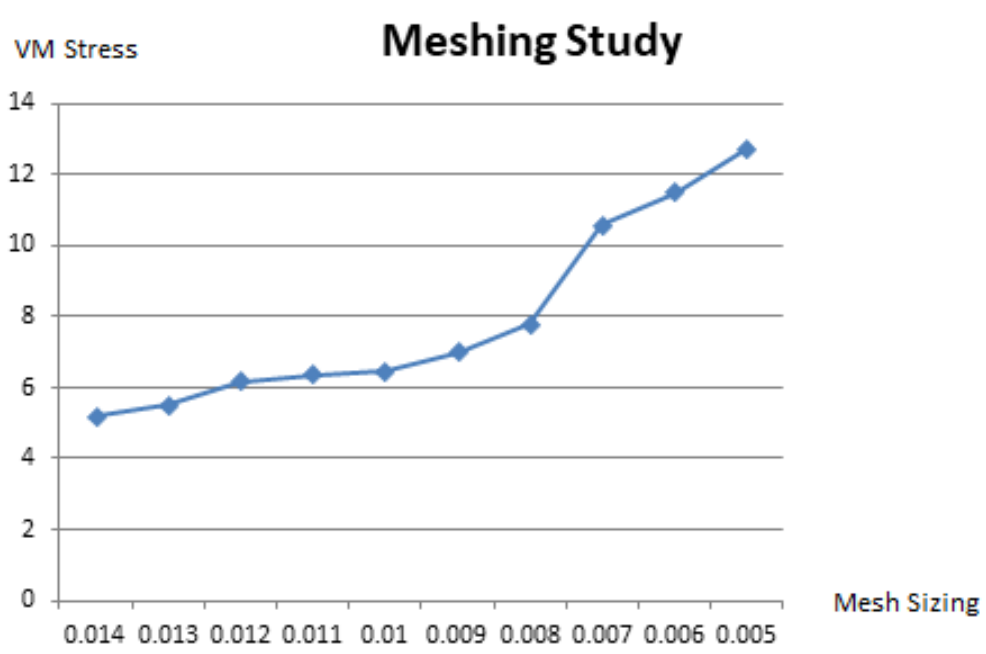

Figure 3. Von-Misses Stress and Mesh Sizing Comparison

The results show that the Von Misses Stress and the Nodes are more stable when the element size is bigger than $0.012 \mathrm{~m}$ and less than $0.01 \mathrm{~m}$. Examine the mesh size at $0.009 \mathrm{~m}$ until $0.005 \mathrm{~m}$. The Von Misses stress result has a big gap from each other up until $35.84 \%$ from $0.008 \mathrm{~mm}$ to $0.007 \mathrm{~mm}$. The researcher concludes that the optimum size for the meshing size for the electric car frame is $0.01 \mathrm{~m}$.

\section{Data Analysis}

Manual Calculation Analysis

Using the assumptions and the given equation above, the result of the manual calculation is as shown below:

Table 4. Manual Calculation Result

\begin{tabular}{|c|c|c|c|}
\hline No. & Method & $\begin{array}{c}\text { Stress Result } \\
\left(\mathbf{N} / \mathbf{m m}^{\mathbf{2}}\right)\end{array}$ & $\begin{array}{c}\text { Deflection } \\
(\mathbf{m m})\end{array}$ \\
\hline 1. & A1 & 114.90 & 4.425 \\
\hline 2. & A2 & 22.25 & 0.79 \\
\hline 3. & A3 & 98.24 & 2.75 \\
\hline 4. & A4 & 167.71 & 6.72 \\
\hline
\end{tabular}

The Methods are:

- A1. Drivers load (100 kg) using the first assumption.

- A2. Machines load (30 kg) using the first assumption.

- A3. The drivers load and the machine load in total $(130 \mathrm{~kg})$ using the first assumption.

- A4. The drivers load and the machine load in total $(130 \mathrm{~kg})$ using the second assumption.

The Calculation shows that the results are less than the allowable stress $177.5 \times 10^{6} \mathrm{~Pa}$. Therefore the result is still in safe limits. 
FEA Results with Software

After doing meshing study, the researcher starts to analyse the data. The first analysis is to find out the Von-Misses stress that appears on the electric car frame. The first analysis was using ANSYS. The researchers input the boundary conditions which includes the loads and fixed support in order to find the Von-Misses Stress.

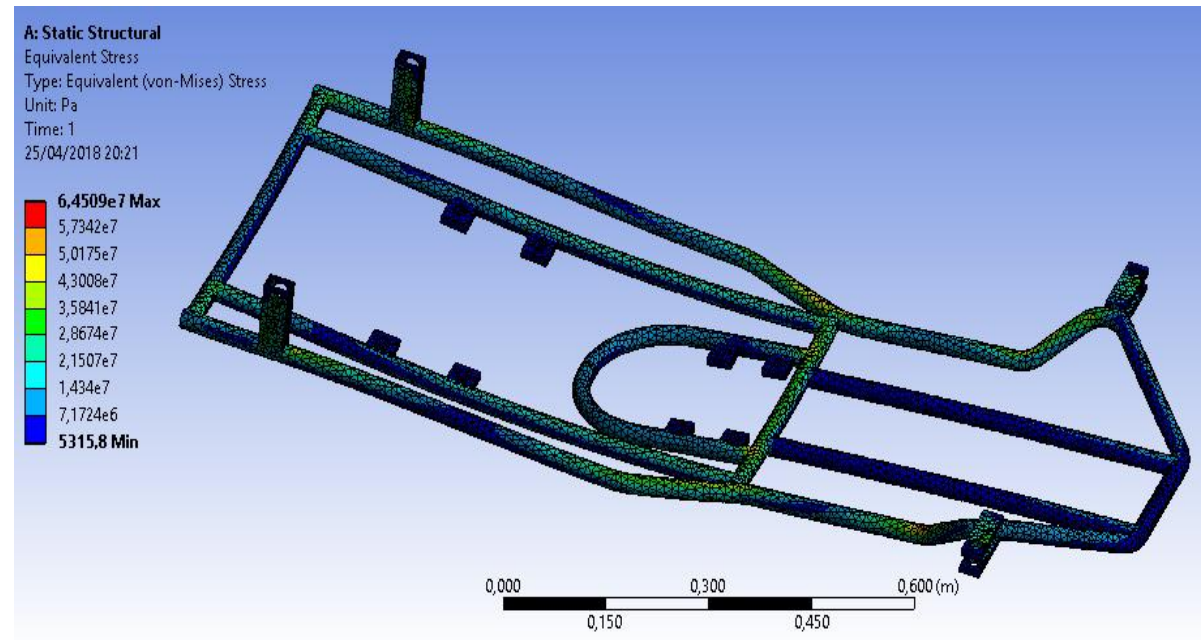

Figure 4. Von-Misses Result

The Analysis shown as in figure 4 above, the ANSYS analysis of the maximum Von-Misses Stress $\left(\sigma_{\mathrm{Vm}}\right)$ that appears on AISI 4130 electric car frame is $6.4 \times 10^{7} \mathrm{~Pa}$. The material used for making this frame is AISI 4130 which has the yield strength of $7.1 \times 10^{8} \mathrm{~Pa}$. Since, the yield strength is greater than the maximum Von-Misses Stress $\left(\sigma_{\mathrm{Vm}}\right)$, the researcher concluded that the electric car frame is in the safe limits. Next is to determine the bending stress that is applied towards the electric car frame. The result is shown in figure 5 below.

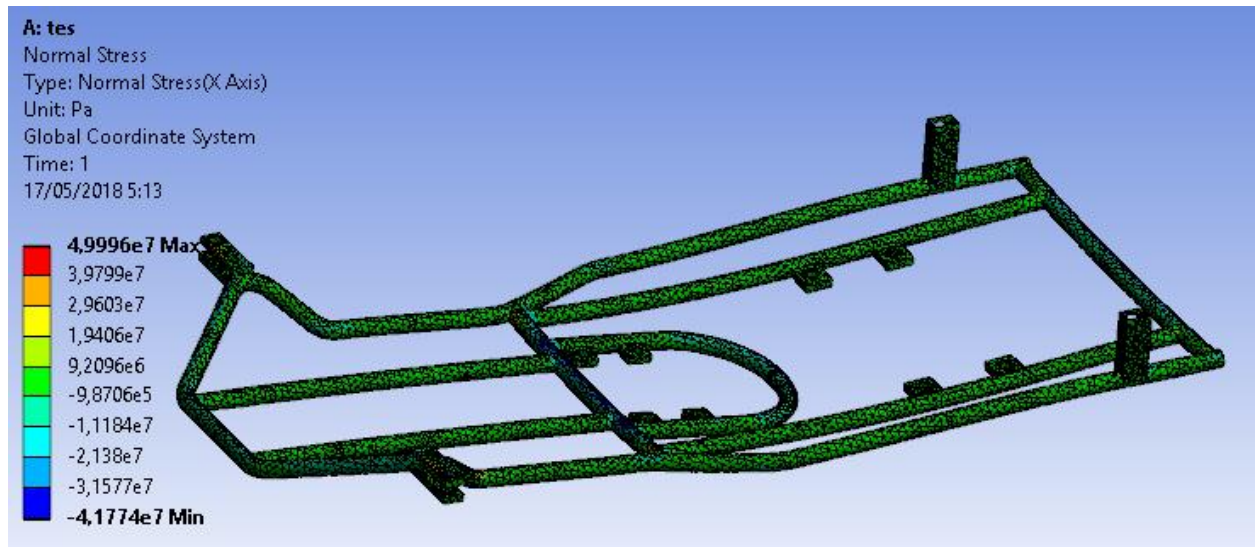

Figure 5. Bending Stress Analysis

As shown as figure above, the ANSYS analysis of bending stress $\left(\sigma_{\mathrm{B}}\right)$ that appears on AISI 4130 electric car frame is $4.9 \times 10^{7} \mathrm{~Pa}$. It is below the yield strength and the allowable stress. The range of deformation is from $0 \mathrm{~m}$ (minimum) $-0.0027 \mathrm{~m}$ (maximum). The next analysis will be about the torsion stress towards the torsion bar.

In ANSYS analysis if we are going to give the torsion moment in a hollow cylinder which is in this case the electrical car frame, it requires contact geometry. The researcher decided to analyse the torsion 
bar part only since if we are going to use the whole frame, the ANSYS analysis will not work since it has too big contact. The first step is to put a fixed support towards the torsion beam. The fixed supports are put in each end of the torsion bar since the end of the bar is not moving. The part that is going to be twisted is given the torsion moment. The torsion moment is input manually through this calculation:

$$
\begin{aligned}
\tau_{\sigma} & =\mathrm{Pxd} \\
\tau_{\sigma} & =1300 \mathrm{Nx} 0.0027523 \\
\tau_{\sigma} & =3.5 \mathrm{Nm}
\end{aligned}
$$

And for the allowable torsion shear stress is the yield strength of the material divided by 12 or as shown in the equation below:

$$
\begin{aligned}
\text { allowable } \tau_{\sigma} & =\frac{\sigma_{\mathrm{y}}}{12} \\
\text { allowable } \tau_{\sigma} & =\frac{7.1 \times 10^{8} \mathrm{~Pa}}{12} \\
\text { allowable } \tau_{\sigma} & =6 \times 10^{7} \mathrm{~Pa}
\end{aligned}
$$

After the torsion bar is given the torsion moment, the next step is start analyzing the torsion stress that is applied towards the frame. The result is shown in figure 6 below.

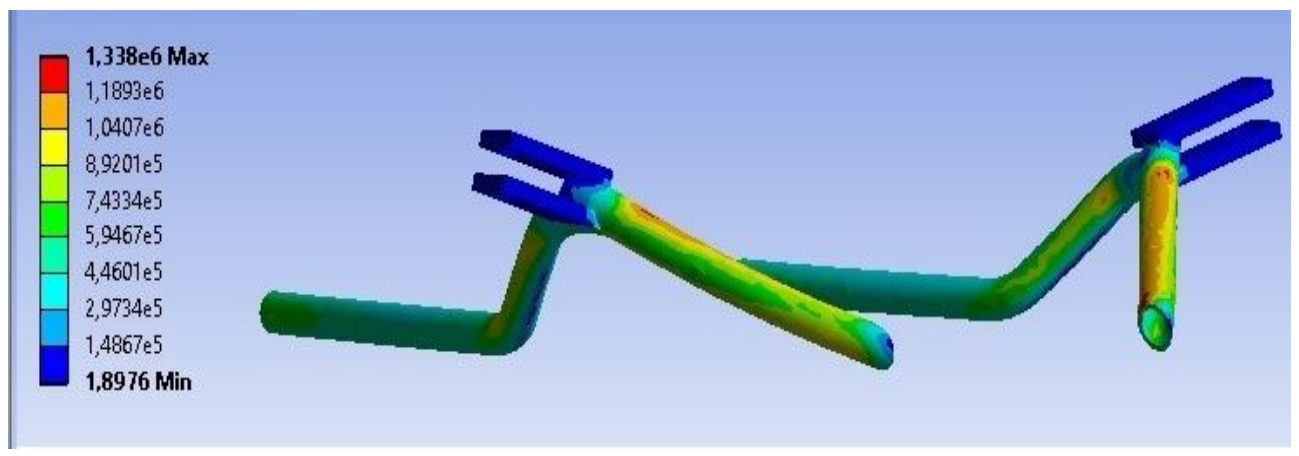

Figure 6. Torsion Shear Stress

As shown in the figure 6, the torsion shear stress is ranged from $1.8-1.338 \times 106 \mathrm{~Pa}$. The maximum Torsion Shear Stress is smaller than the allowable torsion shear stress. In this case it is considered still in safe limits. As the figure shows, the torsion bar levers arm is the most critical place. Since the torsion bar end which supports the levers arm did not move much it is safe to say that the torsion bar works well. Next is to the see the displacement as shown in figure 7. If the displacement is greater than $10 \mathrm{~cm}$, the researcher needs to reconsider the torsion bar geometry.

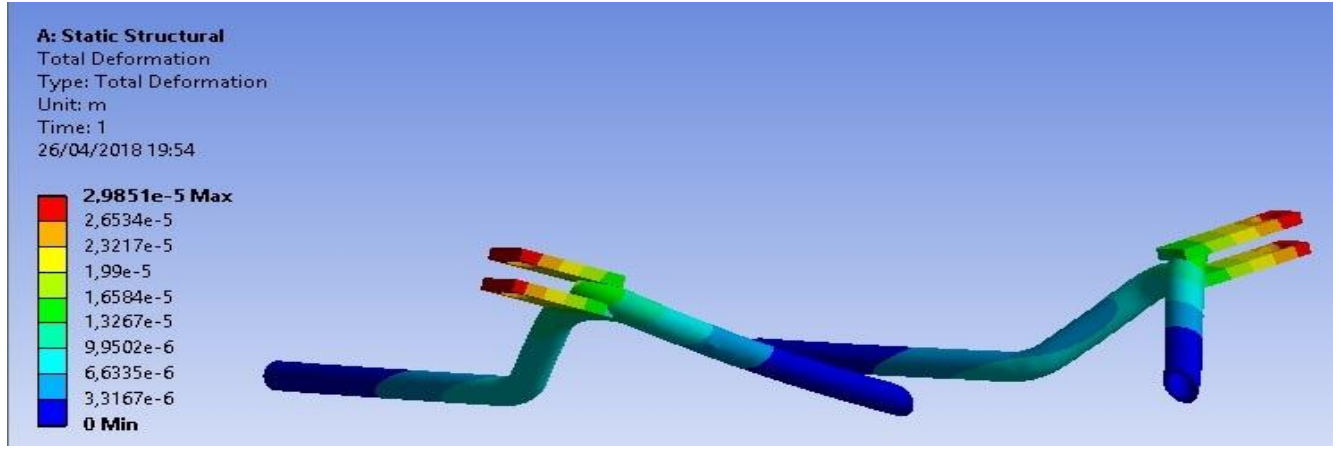

Figure 7. Displacement 
The rear torsion bar turns out to have the maximum torsion shear stress of $1.5257 \times 10^{8} \mathrm{~Pa}$. The stress exceeds the allowable torsion shear stress and therefore needs improvement.

In order to see more torsion stress that appears on the frame, the researcher is going to conduct a dynamic analysis. The researcher's main goal is to see whether the self-suspension frame is working or not. Below are the boundary conditions.

Table 5. Boundary Condition

\begin{tabular}{|l|l|l|}
\hline No. & Boundary Condition & Data Input \\
\hline 1. & Velocity & $40 \mathrm{~km} / \mathrm{h}$ \\
\hline 2. & Spring Condition & No \\
\hline 3. & Force & $1300 \mathrm{~N}$ \\
\hline 4. & Coordinate System & Axis \\
\hline 5. & Frequency Spacing & Linear \\
\hline
\end{tabular}

Assuming the electric car is in a constant velocity of $40 \mathrm{~km} / \mathrm{h}$ and hits a road bump. We are going to see what happens to the torsion bar. Will the levers arm lift or will it stay rigid? If the levers arm lifts a little then we cannot say that this is a self-suspension frame. After we get the displacement we can see the maximum torsion shear stress of the torsion bar. Below is the result as shown in figure 8 .

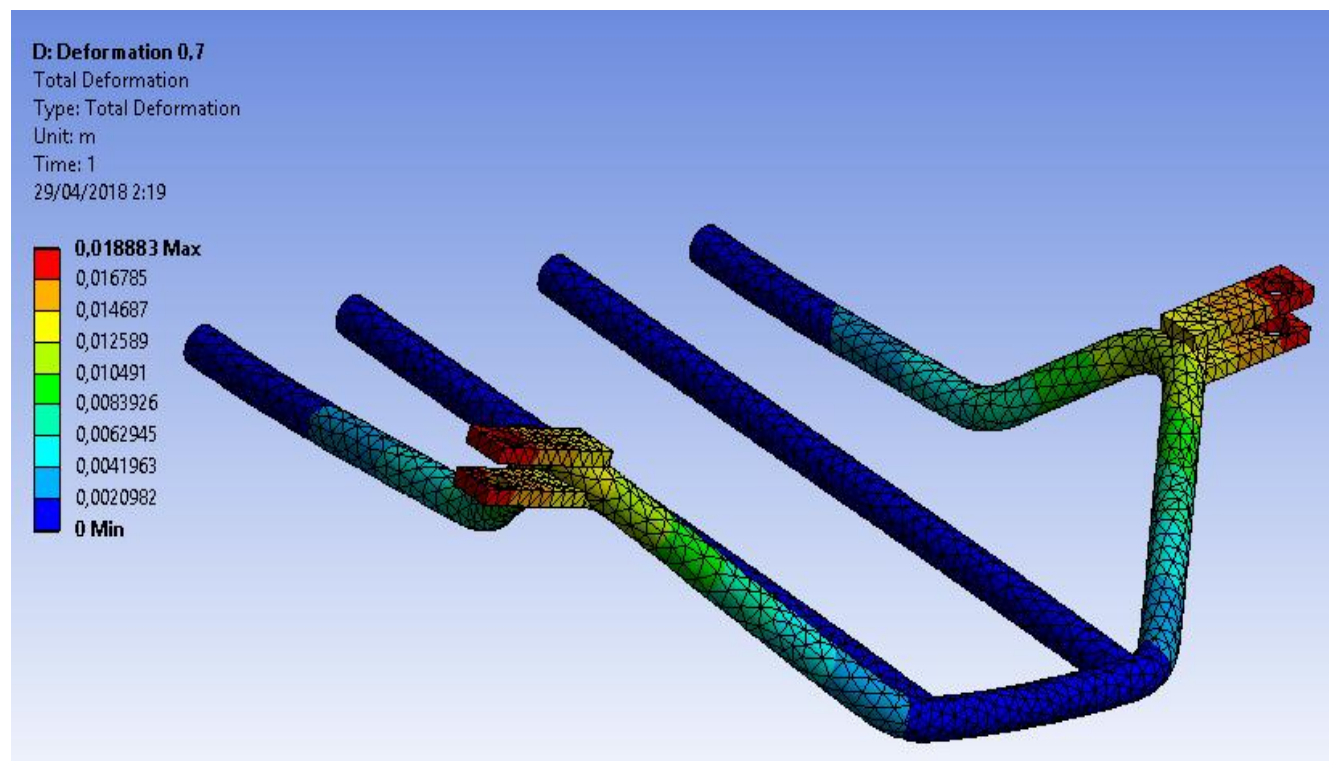

Figure 8. Dynamic Front Torsion Shear Stress Displacement

The levers arm lift around $1.8 \mathrm{~cm}$ which is a good sign that show this geometry can be said as a self-suspension frame. The displacement can now use to find the maximum torsion shear stress. The maximum torsion shear stress is as shown in figure 9. 


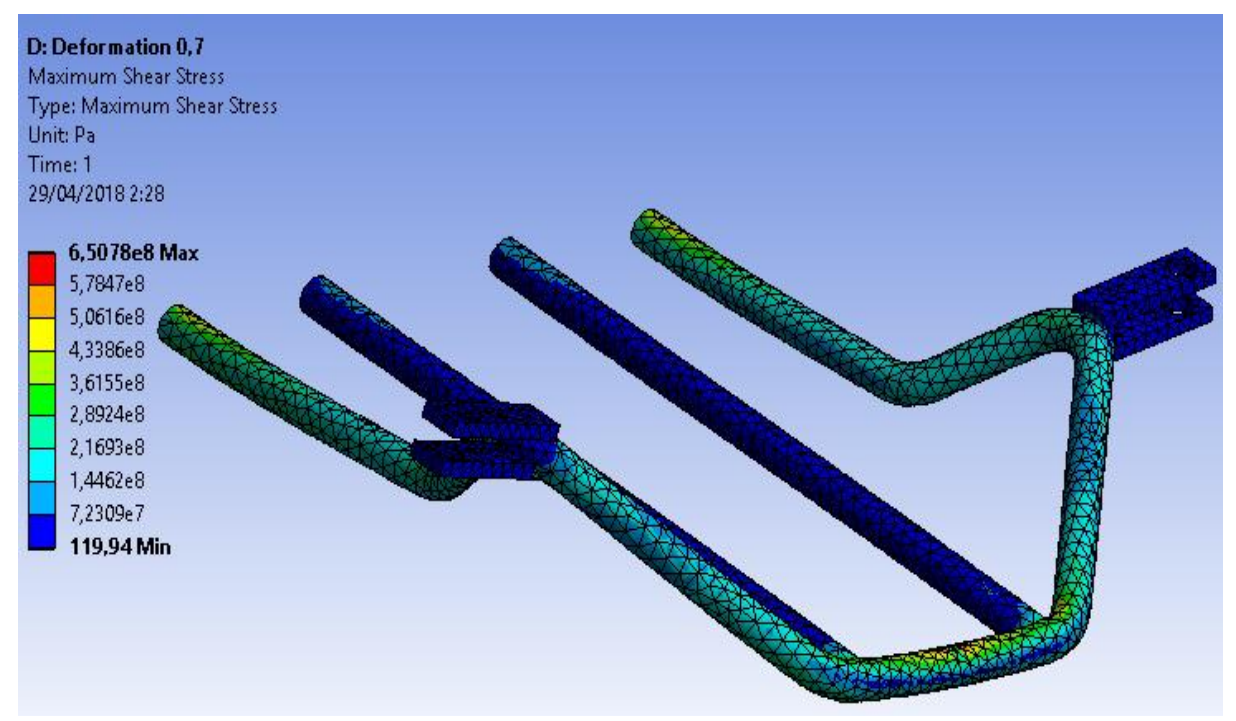

Figure 9. Dynamic Front Torsion Shear Stress

As shown in the figure 9, the maximum torsion shear stress is $6.5078 \times 10^{8} \mathrm{~Pa}$ which is a lot bigger than in a static case which is in $1.8-1.338 \times 10^{6} \mathrm{~Pa}$. The figure shows that the torsion bar cannot handle the current condition. The most displacement is in the wheel mounting which supports in total $1300 \mathrm{~N}$, and the levers arm Thus it is safe to say the torsion bar cannot withstand the given load. As for the rear torsion bar, the same method is used. The results are shown in figure 10.

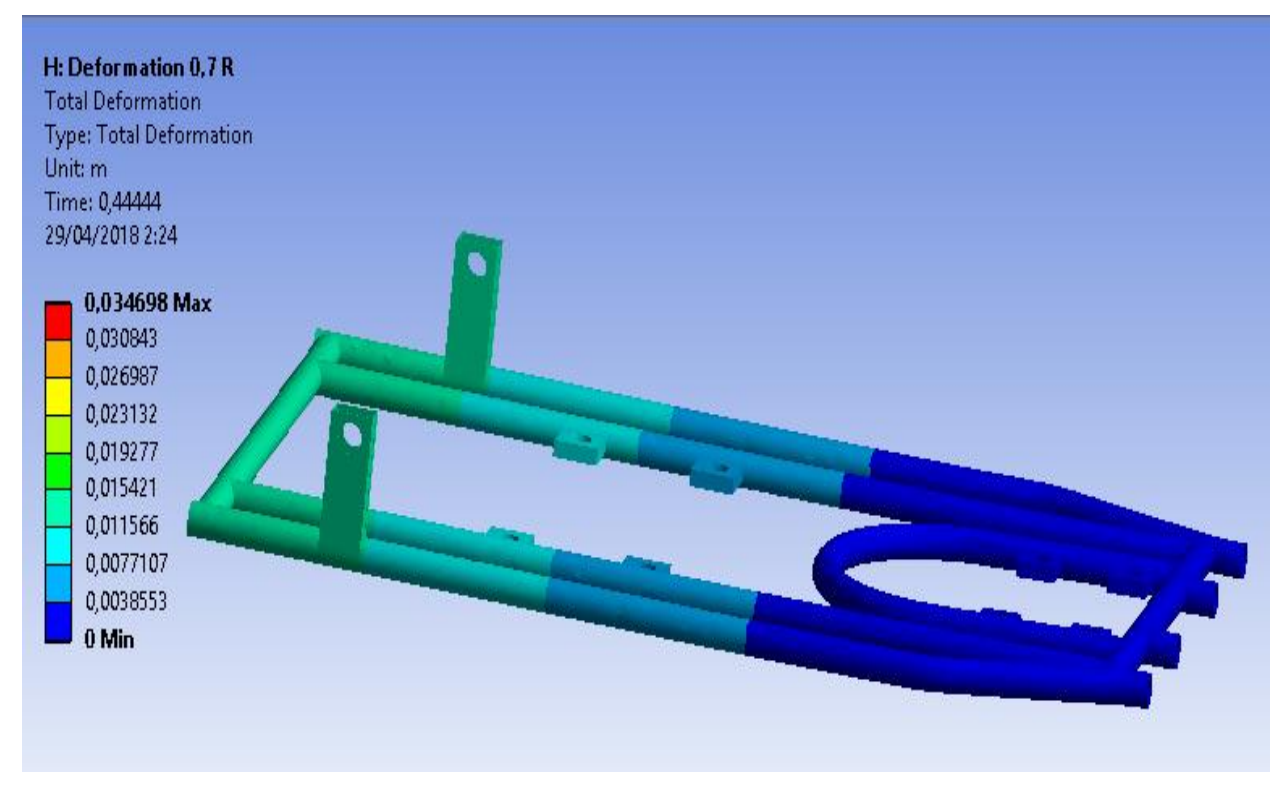

Figure 10. Dynamic Front Torsion Shear Stress Displacement

The rear torsion bar turns out to have displacement of $3.4698 \mathrm{~cm}$. The rear torsion bar is applied to the same force load which is $1300 \mathrm{~N}$. In comparison to the previous static case, the displacement has a major difference. The maximum torsion stress is as shown in figure 11. 


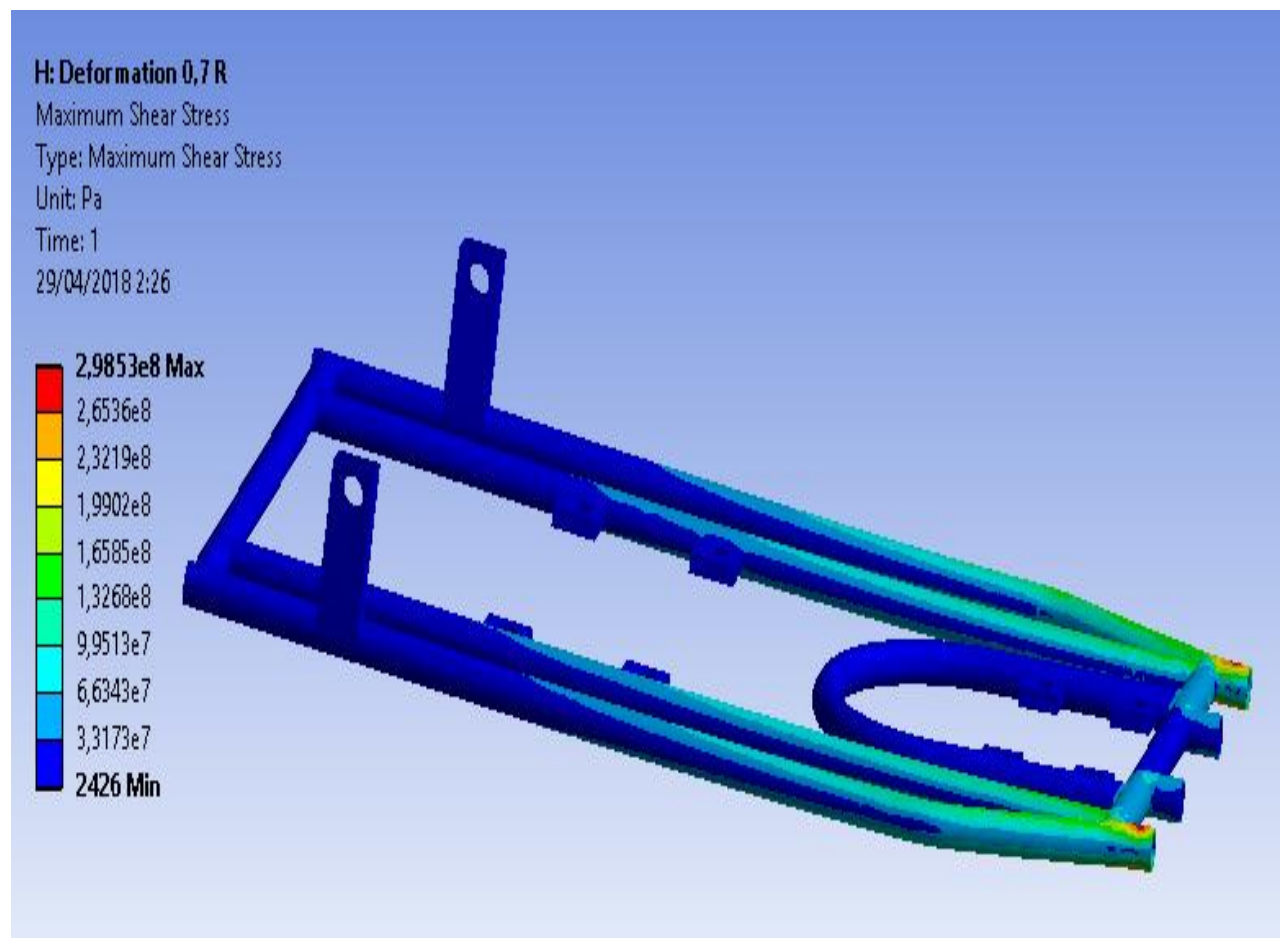

Figure 11. Dynamic Rear Torsion Shear Stress

The rear torsion bar if applied to the same force load, in this case $1300 \mathrm{~N}$, turns out to have the maximum torsion stress of $2.9853 \times 10^{8} \mathrm{~Pa}$, in comparison; it is almost twice as the static case in $1.5257 \times 10^{8} \mathrm{~Pa}$. The analysis in conclusion shows that the torsion bar does not well work while in a dynamic state.

The next analysis will be about the vibration. In vibration analysis, the researcher's first step is to analyse the electric car frame's natural frequency. Every object has its own natural frequency, and when two frequencies collide it will result in a resonance. The electric car chassis consist of both frame and suspension. Thus in a suspension system, if a force is applied, there will be a vibration in the suspension system which is in this case the torsion bar. The analysis will be conducted using ANSYS. The first thing to do is to give the geometry a fixed support in each wheel mounting. Then we can compute.

The result is as show in figure above, the graph from ANSYS shows that the natural frequency of the frame is $58.005 \mathrm{~Hz}$ with the range of $0-0.72188 \mathrm{~m}$ due to the constant vibration. This is the natural frequency of the frame itself. This natural frequency happens at a static moment. Due to be noted this natural frequency does not include the force load of $1300 \mathrm{~N}$. Thus, now we can calculate the in what rpm does the critical frequency of the frame appears. The critical frequency must be calculate in order to see in which rpm, assuming that we are going to put a machine in this frame, will have the greatest resonance since it's vibrates in the same frequency as the natural frequency of the frame.

$$
\begin{gathered}
C_{f}=N_{f} .60 \mathrm{~s} \\
C_{f}=58.005 .60 \mathrm{~s} \\
C_{f}=3480 \mathrm{rpm}
\end{gathered}
$$


Thus the vehicle needs to avoid staying to long at $3480 \mathrm{rpm}$ since it will generate a resonance that will result in an uncomfortable drive. Since an electric car have a range of rpm until 18000, it is wise to say that $3480 \mathrm{rpm}$ can be avoided with ease. There are many reasons why the frame has a high critical frequency. The material selection for example, a kart frame made from carbon steel has the critical frequency at $2400 \mathrm{rpm}$ [7]. Other reason is the pipe thickness. A one inch pipe a small inner diameter, for example, 0.62 inch will have less critical frequency than a one inch pipe with 0.76 inch thickness [7]. Other reason can be due to lack of damper. The mounting does not have any rubber so it creates more resonances. Nothing holds the machine and frame vibration. In result, it creates a greater natural frequency. The common go kart frame has a small critical frequency. The critical frequency ranged from 900-2000 rpm. That is why, it is necessary to improve the design of the mounting damper [5].

The next step is to analyse the torsion bar both rear and front. The goal is to see how many Hertz they generate at static and dynamic motion. The first step is to apply the force load of $1300 \mathrm{~N}$ towards the front torsion bar. Next is to give the fixed support towards the geometry. The result is shown in the figure 12 and figure 13 below.

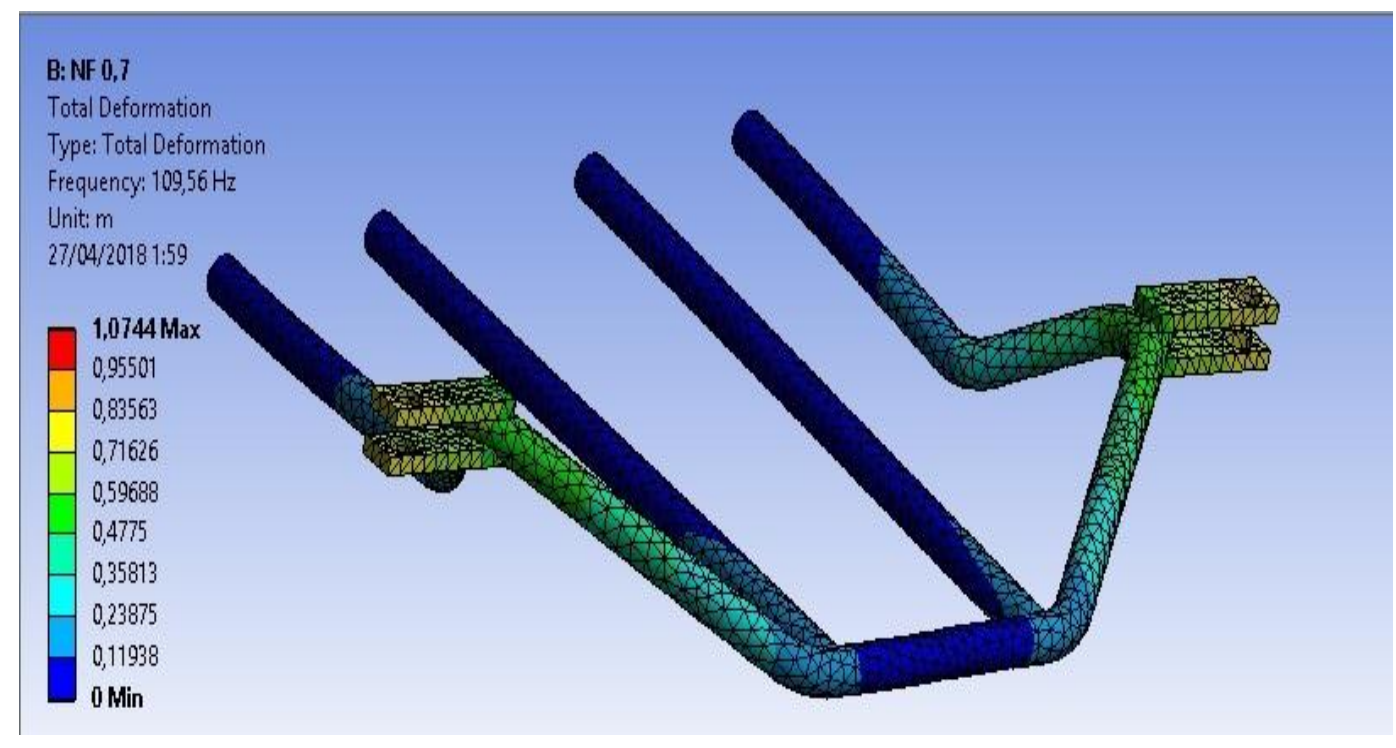

Figure 12. Front Torsion bar First Condition Frequency

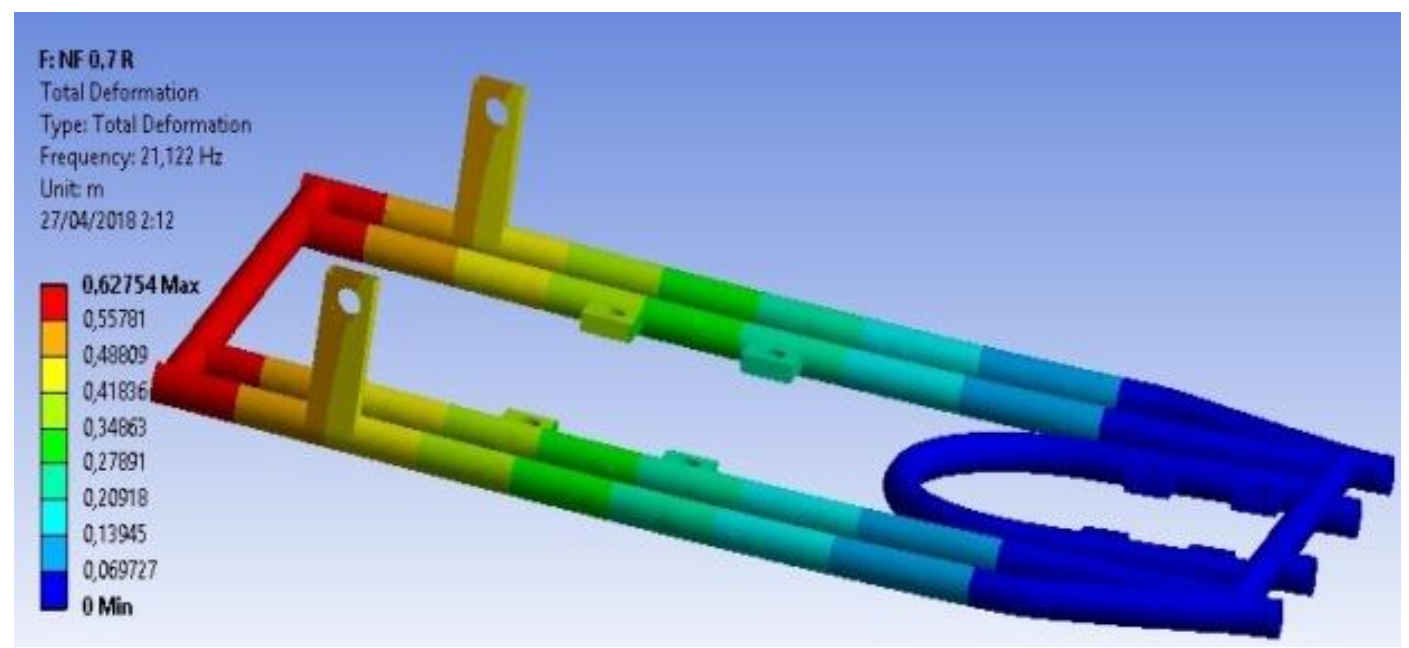

Figure 13. Rear Torsion bar First Condition Displacement Frequency 
The minimum vibration of the front torsion bar is $109.56 \mathrm{~Hz}$. While the rear torsion bar turns out generates less vibration than the front torsion bar. The vibration of the torsion bar is $21.122 \mathrm{~Hz}$ with the max displacement of $0.62754 \mathrm{~m}$.

After the static frequency analysis, the researcher feels it is wise to see what happens when the torsion bar is in a constant dynamic motion. To see the displacements of the vibration the torsion bar generates. In doing so, the researcher uses Harmonic Response ANSYS. The first step is to put the geometry which is the front torsion bar and apply the force towards the torsion bar which is $1300 \mathrm{~N}$. next is to determine the range of the graph. The researcher needs to build the boundary condition in order to generate the analysis as shown in table below.

Table 6. Boundary Condition

\begin{tabular}{|c|c|c|}
\hline No. & Boundary Condition & Data Input \\
\hline 1. & Seconds & $400 \mathrm{~s}$ \\
\hline 2. & Lowest Frequency Range & $0 \mathrm{~Hz}$ \\
\hline 3. & Highest Frequency Range & $400 \mathrm{~Hz}$ \\
\hline $\mathbf{4 .}$ & Velocity & $40 \mathrm{~km} / \mathrm{h}$ \\
\hline $\mathbf{5 .}$ & Spring Condition & No \\
\hline 6. & Force & $1300 \mathrm{~N}$ \\
\hline 7. & Coordinate System & Axis \\
\hline 8. & Frequency Spacing & Linear \\
\hline
\end{tabular}

Next step is to generate the analysis. The result for the front torsion, the vibration at dynamic state will result in $132 \mathrm{~Hz}$ of frequency. The peak amplitude is $9.6678 \times 10^{-2} \mathrm{~m}$. To make it clear, amplitude is the distance of the middle of a wave. As for the rear torsion, the peak condition results in amplitude of $8.4537 \times 10^{-2} \mathrm{~m}$ at the $5^{\text {th }}$ second with $20 \mathrm{~Hz}$ of frequency.

\section{Evaluation}

From the manual calculation and the ANSYS analysis result the data are:

Table 7. Results Comparison

\begin{tabular}{|c|c|c|c|}
\hline No. & Method & $\begin{array}{c}\text { Stress Result } \\
\left(\mathbf{N} / \mathbf{m m}^{\mathbf{2}}\right)\end{array}$ & $\begin{array}{c}\text { Deflection } \\
(\mathbf{m m})\end{array}$ \\
\hline 1. & A1 & 114.90 & 4.425 \\
\hline 2. & A2 & 22.25 & 0.79 \\
\hline 3. & A3 & 98.24 & 2.75 \\
\hline 4. & A4 & 167.71 & 6.72 \\
\hline 5. & A5 & 49.99 & 3.51 \\
\hline
\end{tabular}


The Methods are:

A1. Drivers load $(100 \mathrm{~kg})$ using the first assumption.

A2. Machines load $(30 \mathrm{~kg})$ using the first assumption.

A3. The drivers load and the machine load in total $(130 \mathrm{~kg})$ using the first assumption.

A4. The drivers load and the machine load in total (130 kg) using the second assumption.

A5. The ANSYS Analysis Result.

From the table above we can conclude that the manual calculation number 2 and number 3 using the 1st assumption method has the nearest result towards the ANSYS analysis result. Yet it is only fair to compare the analysis result with the same load which is $130 \mathrm{~kg}$. The range of the result can be written as follows:

\section{Bending Stress}

The result is smaller than the allowable stress which is $177.5 \times 106 \mathrm{~Pa}$. The difference between the ANSYS result and the allowable stress are up to 1:3.5

\section{Displacement}

Due to the assumption of the kart frame as a single beam, there will be a gap between the manual calculation and the result analysis. Thus in conclusion the design needs some improvement.

\section{Improvement}

Based on the previous analysis, the front torsion bar design needs some improvement. The researcher considered on making a better design to ensure the self-suspension or the torsion bar works. The data are as shown in table 8 below.

Table 8. Pipe Dimension

\begin{tabular}{|c|c|c|}
\hline \multicolumn{2}{|c|}{ Dimension } & \multirow{2}{*}{ Material } \\
\cline { 1 - 2 } Inner Diameter & Outer Diameter & \multirow{2}{*}{ AISI 4130} \\
\hline 0,76 inch & 1 inch & \\
\hline
\end{tabular}

The Load Specifications are:

- Frame load : $19,97 \mathrm{~kg}$

- Frame load + driver and machine load : $149,97 \mathrm{~kg}$

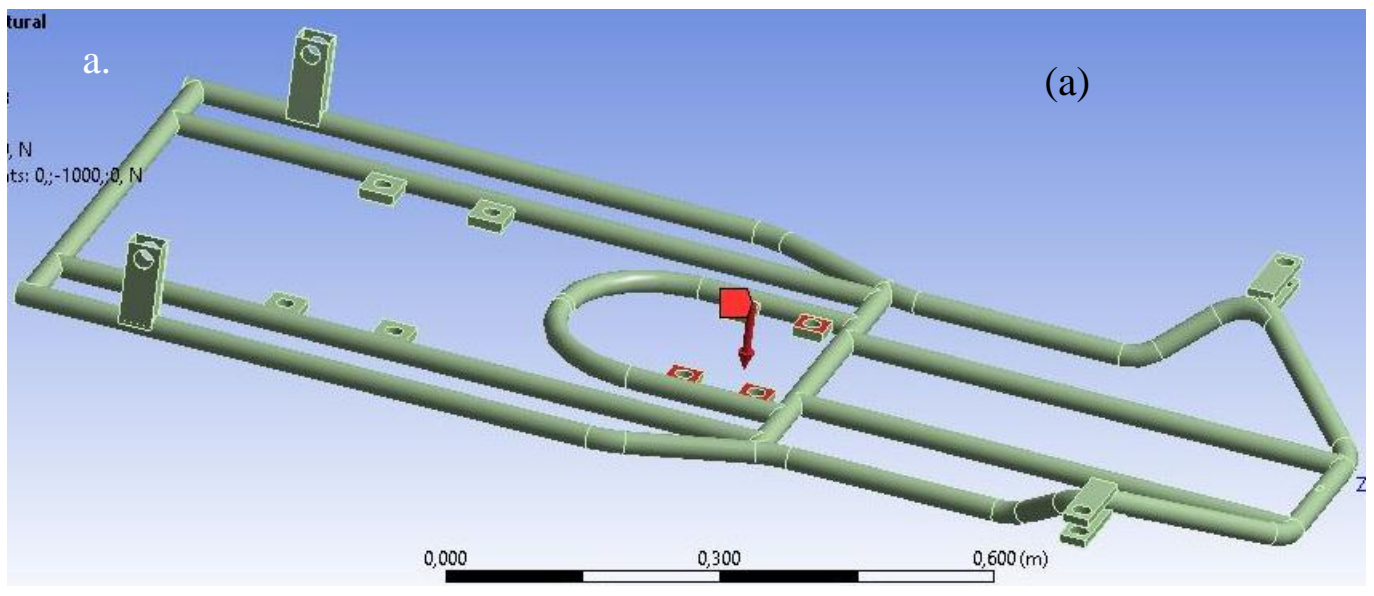




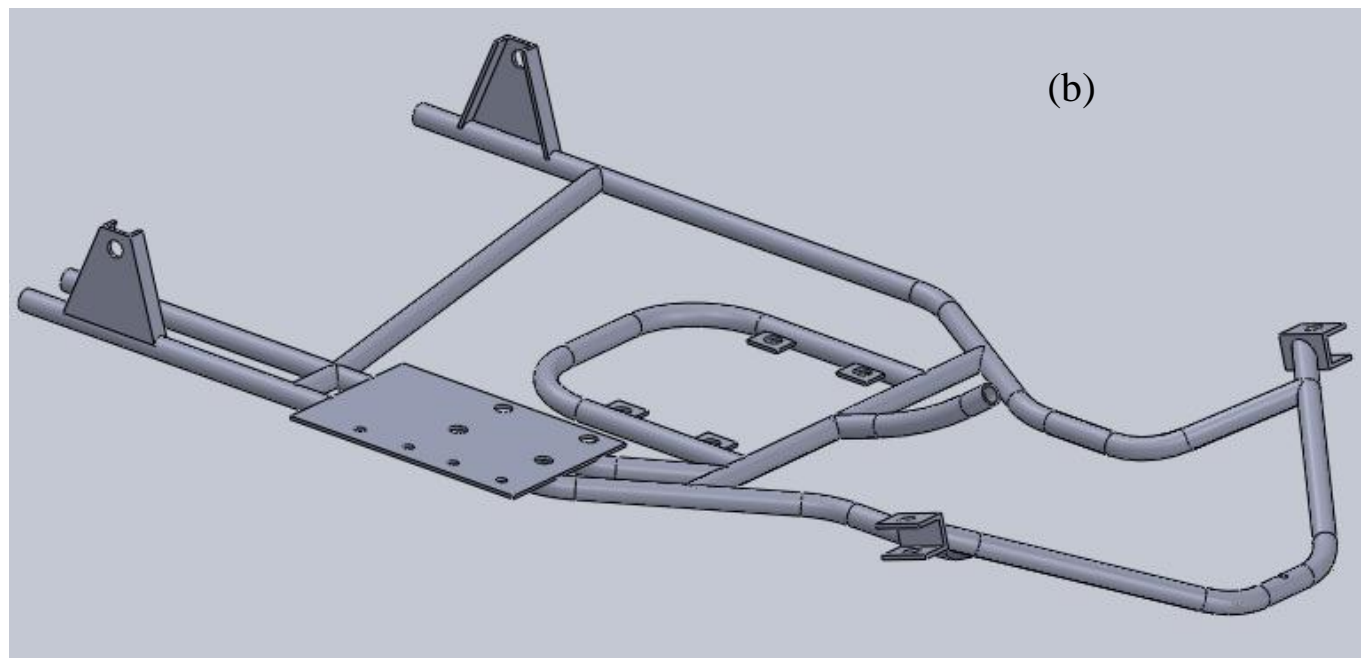

Figure 14. Design Comparison of previous design (a.) and improved design (b.)

The figure 14 above shows the comparison between the previous design (a.) and the new design (b.).The design geometry concept is still the same; the researcher did not enlarge the inner diameter as well. The main change happens on the stabilizer beam, mounting, and the width of the torsion bar. The front wheel mounting are now given a $17^{\circ}$ angle it hope of a better riding quality, rear beam is given one stabilizer with uneven distance towards the bar end. The engine mounting is now positioned at the right side of the frame. As to make this research to the point, the comparison data of the previous design and the improved design are shown in table 9.

Table 9. Design Data Comparison

\begin{tabular}{|c|c|c|}
\hline Von Misses & Previous Design & Improved Design \\
\hline Deformation & $6.4 \times 10^{7} \mathrm{~Pa}$ & $9.4 \times 10^{7} \mathrm{~Pa}$ \\
\hline $\boldsymbol{\tau}$ & $0.0027 \mathrm{~m}$ & $0.0039 \mathrm{~m}$ \\
\hline $\begin{array}{c}\text { Front Torsion Bar Torsion } \\
\text { Shear Stress (Static) }\end{array}$ & $3.5 \mathrm{Nm}$ & $3.2 \mathrm{Nm}$ \\
\hline $\begin{array}{c}\text { Front Torsion Bar } \\
\text { Displacement (Static) }\end{array}$ & $2.9851 \times 10^{-5} \mathrm{~m}$ & $9.0724 \times 10^{-5} \mathrm{~m}$ \\
\hline $\begin{array}{c}\text { Rear Torsion Bar Torsion } \\
\text { Shear Stress (Static) }\end{array}$ & $1.5257 \times 10^{8} \mathrm{~Pa}$ & $1.0167 \times 10^{6} \mathrm{~Pa}$ \\
\hline $\begin{array}{c}\text { Rear Torsion Bar } \\
\text { Displacement (Static) }\end{array}$ & $0.0019153 \mathrm{~m}$ & $0.0021822 \mathrm{~m}$ \\
\hline $\begin{array}{c}\text { Front Torsion Bar Torsion } \\
\text { Shear Stress (Dynamic) }\end{array}$ & $6.5078 \times 10^{8} \mathrm{~Pa}$ & $1.695 \times 10^{8} \mathrm{~Pa}$ \\
\hline $\begin{array}{c}\text { Front Torsion Bar } \\
\text { Displacement (Dynamic) }\end{array}$ & 0.0027 & $0.0024 \mathrm{~m}$ \\
\hline
\end{tabular}




\begin{tabular}{|c|c|c|}
\hline $\begin{array}{l}\text { Rear Torsion Bar Torsion } \\
\text { Shear Stress (Dynamic) }\end{array}$ & $2.9853 \times 10^{8} \mathrm{~Pa}$ & $3.2577 \times 10^{8} \mathrm{~Pa}$ \\
\hline $\begin{array}{c}\text { Rear Torsion Bar } \\
\text { Displacement (Dynamic) }\end{array}$ & $0.034 \mathrm{~m}$ & $0.039 \mathrm{~m}$ \\
\hline $\begin{array}{c}\text { Front Torsion Bar } \\
\text { Constant }\end{array}$ & $65.10^{6} \mathrm{~N} / \mathrm{m}$ & $65.10^{6} \mathrm{~N} / \mathrm{m}$ \\
\hline $\begin{array}{c}\text { Rear Torsion Bar } \\
\text { Constant }\end{array}$ & $65.10^{5} \mathrm{~N} / \mathrm{m}$ & $65.10^{5} \mathrm{~N} / \mathrm{m}$ \\
\hline Bending Stress & $4.99910^{7} \mathrm{~N} / \mathrm{m}$ & $8.945 \cdot 10^{7} \mathrm{~N} / \mathrm{m}$ \\
\hline Natural Frequency & $58.005 \mathrm{~Hz}$ & $52.081 \mathrm{~Hz}$ \\
\hline Critical RPM & $3480 \mathrm{rpm}$ & $3125 \mathrm{rpm}$ \\
\hline $\begin{array}{l}\text { Front Torsion Bar } \\
\text { Frequency (Static) }\end{array}$ & $109.56 \mathrm{~Hz}$ & $59.488 \mathrm{~Hz}$ \\
\hline $\begin{array}{c}\text { Front Torsion Bar } \\
\text { Frequency Displacement } \\
\text { (Static) }\end{array}$ & $0.00113 \mathrm{~m}$ & $0.0016954 \mathrm{~m}$ \\
\hline $\begin{array}{l}\text { Rear Torsion Bar } \\
\text { Frequency (Static) }\end{array}$ & $21.122 \mathrm{~Hz}$ & $18.942 \mathrm{~Hz}$ \\
\hline $\begin{array}{c}\text { Rear Torsion Bar } \\
\text { Frequency Displacement } \\
\text { (Static) }\end{array}$ & $0.627 \mathrm{~m}$ & $0.951 \mathrm{~m}$ \\
\hline $\begin{array}{c}\text { Front Torsion Bar } \\
\text { Frequency (Dynamic) }\end{array}$ & $132 \mathrm{~Hz}$ & $34 \mathrm{~Hz}$ \\
\hline $\begin{array}{c}\text { Front Torsion Bar } \\
\text { Frequency Displacement } \\
\text { (Dynamic) }\end{array}$ & $0.0012 \mathrm{~m}$ & $0.02526 \mathrm{~m}$ \\
\hline $\begin{array}{c}\text { Rear Torsion Bar } \\
\text { Frequency (Dynamic) }\end{array}$ & $20 \mathrm{~Hz}$ & $46 \mathrm{~Hz}$ \\
\hline $\begin{array}{c}\text { Rear Torsion Bar } \\
\text { Frequency Displacement } \\
\text { (Dynamic) }\end{array}$ & $0.00225 \mathrm{~m}$ & $0.00125 \mathrm{~m}$ \\
\hline
\end{tabular}

The table shows us that the improved geometry has result like expected. The Von-Misses Stress even though is greater than the previous geometry is still in a safe limit. The Displacement when the geometry is in static moment however is outstanding. The front torsion bar has a better displacement compared to the previous design. The rear torsion bar at a dynamic motion has a better rebound than the previous design. To make it easier to see how well the improvement is, the researcher will compare the result with Yamaha Scorpio Suspension in table 10 below. 
Table 10. Head to head Comparison

\begin{tabular}{|c|c|c|c|c|}
\hline & Force & $\begin{array}{c}\text { Displacement } \\
\text { Previous }\end{array}$ & $\begin{array}{c}\text { Displacement } \\
\text { Yamaha }\end{array}$ & $\begin{array}{c}\text { Displacement } \\
\text { Improved }\end{array}$ \\
\hline Front Suspension & $\begin{array}{c}1300 \mathrm{~N} \\
\text { (Static) }\end{array}$ & $0.002 \mathrm{~cm}$ & $0.5 \mathrm{~cm}$ & $0.002 \mathrm{~cm}$ \\
\hline Rear Suspension & $\begin{array}{c}1300 \mathrm{~N} \\
(\text { Static) }\end{array}$ & $0.2 \mathrm{~cm}$ & $1.4 \mathrm{~cm}$ & 0.02 \\
\hline Front Suspension & $\begin{array}{c}1300 \mathrm{~N} \\
(\text { Dynamic) }\end{array}$ & $1.8 \mathrm{~cm}$ & $3.9 \mathrm{~cm}$ & $2.4 \mathrm{~cm}$ \\
\hline Rear Suspension & $\begin{array}{c}1300 \mathrm{~N} \\
(\text { Dynamic) }\end{array}$ & $3.5 \mathrm{~cm}$ & $4.2 \mathrm{~cm}$ & $3.9 \mathrm{~cm}$ \\
\hline
\end{tabular}

The table shows us that the improved geometry has a great result even if it is compared to a common suspension like Yamaha Scorpio. Thus, this does not end the researchers' analysis even though it has already answered the objectives. The manual calculation as a validation and comparison will be done.

Table 11. Result

\begin{tabular}{|c|l|c|c|}
\hline No. & \multicolumn{1}{|c|}{ Method } & Stress Result & Displacement \\
\hline 1. & Assumption for $130 \mathrm{~kg}$ of weight & $114.908 \mathrm{~N} / \mathrm{mm}^{2}$ & $1.355 \mathrm{~mm}$ \\
\hline 2. & ANSYS Result & $89,455 \mathrm{~N} / \mathrm{mm}^{2}$ & $3.9 .23 \mathrm{~mm}$ \\
\hline 3. & Assumption for $130 \mathrm{~kg}$ of weight & $114.908 \mathrm{~N} / \mathrm{mm}^{2}$ & $5.874 \mathrm{~mm}$ \\
\hline
\end{tabular}

From th table 11 above we can conclude that the manual calculation with the 1 st and 2 nd method has the nearest result towards the ANSYS analysis result. The first assumption use in both number one and two methods is near the ANSYS result. The range of the result can be written as follows:

\section{Bending Stress}

$$
36.736 \frac{\mathrm{N}}{\mathrm{mm}^{2}}<89.455 \frac{\mathrm{N}}{\mathrm{mm}^{2}}<159.192 \frac{\mathrm{N}}{\mathrm{mm}^{2}}
$$

\section{Displacement}

$$
1.355 \mathrm{~mm} \quad<3.9 .23 \mathrm{~mm} \quad<5.874 \mathrm{~mm}
$$

Due to the assumption of the kart frame is a single beam, there will be a gap between the manual calculation and the ANSYS result. Thus, according to James M. Gere[3], Budynas-Nisbett[1] and Lindeburg[6] from mechanical[4], an association of engineering, this manual calculation equation is valid. 
Journal of Mechanical Engineering and Mechatronics

ISSN: 2527-6212, Vol. 3 No. 2

(C) 2018 Pres Univ Press Publication, Indonesia

\section{Conclusion}

After collecting and analysing all required data, there are several conclusions that can be drawn to answer the objective of the research. The conclusions that can be obtained from the research are:

- The researcher has design an electric car chassis with self-suspension. The design has been through engineering design methodology and analysis so it is safe to say the design works well and is in the safe limits. The design will be attached in the appendices section.

- $\quad$ The chassis successfully withstand the given load with the final result of Von-Misses Stress of 9.4 $\mathrm{x} 107 \mathrm{~Pa}$ but with a great damping ability which can displace itself until $3.9 \mathrm{~cm}$ and back to its original position. With the maximum Vibration of $60 \mathrm{~Hz}$ and a natural frequency of $52 \mathrm{~Hz}$. With a capability to withstand more than 5.2 Nm of torsion moment, and $3.2577 \mathrm{x} 108 \mathrm{~Pa}$ of torsion shear stress. The design showed that a frame with self-suspension technology is possible.

\section{Recommendation}

The proposed strengthening mechanism in this research is indeed still lacking in so many aspects. Hopefully, in the future, there will be more research in order to improve the self-suspension technology in the torsion bar area, the power train area, etc. whether the power train is using chain or better yet using a differential gear method. Hopefully in the coming future, it is suggested for the future research to develop more about the suitable material and design for a self-suspension material in order to create a better and stronger chassis in a cheap cost.

\section{References}

[1] Budynas-Nisbet. "Shigley's Mechanical Engineering Design," 8th Ed.

[2] Daryl L. Logan. 2011. A first course in the finite element method. Cengage Learning.

[3] Gere, James M. "Mechanics of Materials," 6th Ed.

[4] https://mechanicalc.com/reference/beam-analysis

[5] K, Bhushan . 2016. Modal Analysis of Go-karts Chassis Based on FEM and FFT Analyzer.

[6] Lindeburg, Michael R. "Mechanical Engineering Reference Manual for the PE Exam," 13th Ed.

[7] N.A.Z. Abdullah. Dynamics properties of a Go-kart chassis structure and its prediction improvement using model updating approach. UMP Publisher.

[8] Tai-Ran Hsu, "Major Steps In Finite Element Analysis" taken online from: http://www.sjsu.edu/me/facultystaff/faculty/tai-ran-hsu/Ch3_Steps_in_FEM.pdf

[9] R. S. Khurmi. A textbook of machine design. 2005. 